\title{
Implicit Beliefs, Explicit Practices? - How International Human Rights Law Manages Religion
}

In this article, I discuss how international human rights law (IHRL) interacts with the notions of "implicit" and "lived" religion. More specifically, I examine the capability of article 9 on the freedom of thought, conscience and religion in the European Convention on Human Rights (ECHR) to provide protection for rights claims that derive from "implicit" and "lived" forms of religion. I develop this argument in three steps: First, I provide a working definition of "implicit" and "lived" religion. Second, I assess the provisions on the freedom of thought, conscience and religion in the ECHR, asking what kinds of "religion" are most likely to gain protections under this instrument. Third, I review some recent cases to come before the European Court of Human Rights (ECtHR), which monitors the ECHR, gauging which forms of religion have been recognized by the court.

\section{Implicit Religion, Lived Religion?}

Providing a tentative definition of implicit religion necessarily includes discussing the work of Edward Bailey, who more or less singlehandedly coined the term and started the scholarly network and journal that still carries its name. Because of the strong and unequivocal bond between Bailey's work and the term "implicit religion", any attempt at definition by a newcomer to the field such as the present author inevitably risks offending and misconstruing Bailey's work as it appears to theory specialists who are intimately familiar with the entire academic production of the founder of their field. Hence, my treatment of Bailey's work is that of the generalist's impressions from the outside, not that of the theory specialists' deep and profound knowledge, succumbing to the fate of the theory generalist as depicted in Murray S. Davis' classical article "That's Classic!":

Each classical social theory 'looks different' to those who specialize in them and those who don't. Specialists view the theory as an increasingly clear, highly articulated organization of many concepts and their complex relations (as well as a collection of definite problems with some of these concepts and relations). Generalists, on the other hand, have only an indistinct 'general impression' of the theory, which they experience as a loose organization of a few famous concepts, the clichés' of the theory.

Davis 1986: 294

Although my approach to "implicit religion" will thus necessary carry the hallmark of the generalist general impressions, loose organizations and clichés - it will also be marked by the inherent ambiguity and incompleteness of the concept itself. To paraphrase Davis once more, however, the ambiguity and incompleteness of implicit religion is certainly not to the "embarrassment" that Thomas Kuhn identified for incomplete theories in the natural sciences, but is rather crucial to the success of any social theory, as ambiguity invites different interpretations that can take the concept in new directions (Davis 1986: 295-296). Hence, and fortunately, any misconstruals I may make of the concept may actually help propel its application in new and unexpected directions - in this case the direction of law.

With these caveats in mind, I start my investigation of "implicit religion" with Bailey's own definition, as a term that denotes a general aspect of human activity that can be described in three distinct, yet overlapping ways, namely that of (1) commitments, (2) integrating foci and (3) intensive concerns with extensive effects (Bailey 2009: 801-802). According to Bailey, the growing use of the concept in any of these three senses attests to the increased recognition of the reality to which it claims to refer, more specifically

.... a general shift in contemporary culture, towards acceptance of both the propriety and facticity of the implicit, the inarticulate, the unconscious, the mystical, the symbolic, the emotional, the popular, the corporate, the spiritual, the personal, the autobiographical, the anecdotal and the confessional. 
Understood in this way, the notion of implicit religion helps us render identifiable a universal human propensity to cultivate Tillichian "ultimate concerns", albeit a more general and sociable variety that is both less ultimate and less "cerebral and serious" than the sterner variety identified by Tillich (Bailey 2009: 802). On this reading, implicit religion appears to be more or less the "stuff" from which explicit, recognizable and conventional (whatever that means) notions of religion emanate. By leapfrogging over the much discussed sacred/secular divide and offering a criterion of the measurement of commitments as a tool to study degrees of "religiousness" instead of the clear-cut boundaries of "religion", implicit religion as construed by Bailey tries to resolve some of the definitional challenges raised within the study of religion (Bailey 2009: 808).

Although implicit religion has become a useful term for scholars who work with forms of religiosity or religion-like phenomena that occur at the fringes or outside the boundaries of "explicit" or "typical" forms of religion, the term has never entered the global lexicon of scholarly conversations. The majority of articles that come up for the term in search engines like Google Scholar have been published in The Journal of Implicit Religion (1998->), and handbooks, encyclopedias and manuals for the study of religion tend not to provide entries that flesh out the key aspects of the concept - with the exception of the Oxford Handbook of the Sociology of Religion (2009), for which Bailey provided a brief explanation of the concept. While no singular cause for this inability to "catch on" can be identified, the failure of implicit religion to "...collide with something [the] audience holds dear" (Davis 1986: 290) may be part of the explanation: After all, the way in which Bailey constructed implicit religion as a general feature of humankind that is evident everywhere does little to disturb or unsettle established studies of "religion". Because this claim is so uncontroversial, the studies and propositions that have followed in the wake of studies on implicit religion carry none of the transformative potential of theories of "secularization" or "secularism", both of which have become subject to intensive scholarly debates over the last decades, as academics see the core constitutive concept of their disciplines under siege. ${ }^{1}$

Another likely cause for the relative marginality of implicit religion in the scholarly lexicon is the growth in studies of "lived" religion from the middle of the 1990s and onwards, which has attracted the attention of scholars that may otherwise have been interested in "implicit" religion. Much like implicit religion, scholars of lived religion have used the term to highlight the ways in which "ordinary" people live out their religious allegiances in their "everyday" lives. These forms of religiosity often take on forms and functions in people's lives that are far removed from the higher echelons of organized religious communities and established doctrines and practices within what, for lack of a better word, is maintained within more "explicit" forms of religion. An important difference between scholars who study implicit and lived religion is the emphasis on embodiment and practices among the latter: the majority of studies of "lived religion" stress the material and practical aspect of peoples' religious lives over the doctrinal aspects of belief and conscience, or "...domains of life where sacred things are being produced, encountered, and shared" (Ammerman 2016: 89). By preserving the centrality of sacrality as a core aspect of their studies, scholars of lived religion retain a link with more conventional definitions of religion, from Émile Durkheim to William James, all of whom stressed the procedural aspects of determining and relating to a purportedly special, set apart domain of human existence.

Because of its emphasis on the practical aspects of religiosity, the notion of "lived religion" holds great promise for scholars working with the relationship between law and religion: The majority of legislative

\footnotetext{
${ }^{1}$ Arguably, much of the debate concerning secularization and secularism appears to be based on fairly limited readings of actual secularization theory. See in particular Gorski 2000 and Gorski and Altinordu 2008 for useful discussions of the "secular" that are explicitly and carefully grounded in the theories under review.
} 
acts, court cases and legal debates about religion revolve around the practical aspects of the ways in which people live out their religious commitments, from the provision of wedding cakes and the accommodation in bed and breakfasts to the wearing of the full face veil and the catering to dietary requirements within different religious traditions and the accommodation of religion in the workplace. Because people tend to live out their lives in more complicated and less principled ways than those envisaged or prescribed in doctrines and by clergy, the "canons" and core aspects of religions are rarely helpful in determining the proper boundary of law's engagements with religion.

By providing both scholars and legal practitioners with a more nuanced vocabulary to denote how people live their religious lives, "lived religion" can help connect the intentions and effects of legal regulation with the ways in which people perceive the role of religion in their everyday practices. One example of how "lived religion" plays out in jurisprudence is the turn towards "sincerity" as the measurement of beliefs worthy of legal protection in the jurisprudence of the Supreme Court of Canada. Both Anna Su and Lori Beaman have noted how this concept comes closer to "lived religion" than interpretations that stress the real or perceived overlap with established religious orthodoxy (Su 2016: 41, Beaman 2012: 277).

In the US, Winnifred Sullivan has been critical of the approaches of judges to privilege higher, more orthodox varieties of "religion" as more worthy of protection than the heterodox practices of "ordinary" believers (Sullivan 2005: 150-156), a pattern that Elizabeth Shakman Hurd has also detected in the US engagement for religious freedom abroad (Hurd 2015). Mathijs Pelkmans, on the other hand, has highlighted how the inability of law to account for the complexity of "lived religion" in no small part explains why the Soviet Union was unable to eradicate the lived, "cultural" and less formal aspects of people's religious lives (2014: 444). Discussing the approaches of the European Court of Human Rights to religious materials, Méadhbh McIvor has suggested that the court's interpretations of Article 9 are "...somewhat ill-equipped to deal with the experience of lived religion" because of its emphasis on belief over practice and its tendency to "downplay the centrality of objects in the creation and expression of religious worlds" (McIvor 2015: 5).

Taken together, these approaches to how law interacts with lived religion in different settings provide vital correctives to the field of law and religion. These correctives have helped highlight how the incompleteness and shortcomings of law in the regulation of religion can both be detrimental and conducive to "lived religion", that the taxonomies and vocabulary of legal regulations go a long way in determining which aspects of "religion" will gain legal recognition, but also that these taxonomies can be modulated through judicial interpretations and precedent.

So far, however, the interest among scholars working with law and religion in the interaction between the legal regulation of religion and "implicit" religion has, at least to my knowledge, been all but nonexistent. Unlike lived religion, implicit religion provides no expansion of "religion" from its "core", or "explicit" forms. Rather, the virtue of implicit religion is its capacity to deny any core or periphery to whatever we come to call "religion", stressing instead the sheer variety of commitments and integrating foci that make life worth living.

Put to that infamous test of the applicability of any given definition in introductory courses in comparative religion - whether football fandom qualifies as a religion or not - the notion of implicit religion would appear to readily provide an unequivocal confirmation. As Edward Bailey pointed out, however, the point of designating football fandom as an implicitly religious practice is not in the act of watching a football match in itself, but rather in the influence it has on the rest of the week, or by its influence on what lies outside the particular activity (Bailey 2009: 802). Implicit religion, on this reading, 
clearly demarcates a different aspect of social life than "lived" religion, which would only be applicable to aspects of football fandom that involved some form of extraneous and non-doctrinal, yet clearly identifiable "religious" element, by virtue of providing a "sacralized" focal point for a particular kind og commitments.

Drawing on this expansive notion of "implicit religion", Sharon Hanson has suggested that English law owes a "...cultural debt to Christianity", which has been decisive to the structure and vocabulary of law, which has contributed to "Christianity's privileged position within English law and culture." (Hanson 2007: 32). In Hanson's analysis, English law displays some of the tell-tale signs of implicit religiosity, which in turn leads to a discriminatory preference for (explicit) Christianity, which is portrayed as the normal and acceptable standard of religiosity in case-law on religion.

Taken together, then, earlier research on law and "lived" religion and law and "implicit" religion has served to highlight the bias of legal systems towards forms of religiosity that resemble established majority traditions. This bias occurs both structurally and practically, as it can be detected in the taxonomies of legal regulation and in the vocabulary of jurisprudence. Such bias affects the legal status of different segments within majority religious traditions, where legal frames of reference will tend to favor orthodox, "explicit" and formally sanctioned varieties of religious beliefs and practices, but also leads to the potential discrimination between different religions, where the lesser-known traditions of religious minorities will frequently tend to enjoy weaker protections.

Despite their similarities, however, the "lived" and "implicit" modulations to "religion" offer different repertoires for scholarly analysis: where the notion of lived religion offers a different, embodied and heterogeneous take on the perpetual differentiation between sacrality and secularity, implicit religion offers a distinctive vocabulary to denote and examine the broad range of social commitments that can play roles that are comparable to those of more conventional forms of "religion" Hence, where lived religion stresses differences, implicit religion invites the search for similarities, or analogues. In this particular sense, implicit religion works similarly to legal reasoning, which is premised on the continuous abstraction, comparison and similarity between different cases.

\section{The Religion of International Human Rights Law}

Few legal subfields offer more challenging and contentious attempts at analogy and similarity than law and religion: The propensity of legislators and legal practitioners to favor aspects of "religion" that resemble those that have the longest history in the domestic legal, political and cultural surroundings is well-documented, and has been condoned by the established practice of the European Court of Human Rights to grant states a "margin of appreciation" to set their own legal boundaries in cases concerning religious manifestations where there is no apparent "European consensus" (Itzcovich 2013: 296).

Apart from fairly limited concessions towards the traditions of majority religions, the ECtHR has been unequivocal in its support for a broad conception of protected beliefs and a strict examination of any attempts by states to hinder "manifestations" inspired by such beliefs: The ECtHR has recognized marginal traditions that go well beyond established religions, such as Aumism, Scientology and Raelianism, and has also been vocal in its support for established, yet controversial minority faiths such as the Jehova's Witnesses in Russia and the Alevis in Turkey. Repeatedly stressing that the threshold for protection under the freedom of religion or belief in article 9 of the European Convention on Human 
Rights is not limited to conventional forms of "religion", the court has observed that protections can be granted to any "views that attain a certain level of cogency, seriousness, cohesion and importance". 2

A similar approach has been developed at the UN Human Rights Committee, which oversees the implementation of the International Covenant on Civil and Political Rights (ICCPR), whose article 18 provides roughly the same kinds of protections as article 9 of the ECHR. Because of the similarity between the provisions, the ECtHR has repeatedly cited the interpretation of article 18 provided by the committee. In its General Comment no. $22,{ }^{3}$ elaborating on the conceptions of "religion" that are worthy of protection under article 18 of the ICCPR, the committee came stumblingly close to Bailey's concept of implicit religion:

1. The right to freedom of thought, conscience and religion (which includes the freedom to hold beliefs) in article 18.1 is far-reaching and profound; it encompasses freedom of thought on all matters, personal conviction and the commitment to religion or belief, whether manifested individually or in community with others. (...) 2. Article 18 protects theistic, non-theistic and atheistic beliefs, as well as the right not to profess any religion or belief. The terms "belief" and "religion" are to be broadly construed. Article 18 is not limited in its application to traditional religions or to religions and beliefs with institutional characteristics or practices analogous to those of traditional religions.

These expansive interpretations of "religion", and their attendant willingness to bring concepts related to the "commitments" and "integrating foci" of Bailey within the ambit of the freedom of religion would seem to suggest that both the Human Rights Committee and the European Court of Human Rights are premised on the explicit recognition of implicit forms of religiosity.

The determination of whether a specific commitment, thought or conviction reaches the threshold of protection, however, tells only one part of a larger story. Most cases that come to the attention of legislators and courts do note hinge on whether the belief, conviction or commitment in question falls within the ambit of protection, but on the permissible limits to "manifestations" of this particular belief. This is where the analogy to "implicit" religion breaks down: the term "manifestations" carries implications and associations that are considerably more limited and specific than the more open-ended notion of "thought, conscience and religion".

This is not only a question of semantics, but has also been reflected in the work of the Human Rights Committee and the ECtHR. The Human Rights Committee has developed a distinction between manifestations that give "direct expressions" to belief and acts that are "integral" to belief, both of which fall within the scope of protection under article $18 .{ }^{4}$ The ECtHR has narrowed down the scope further: In the case of Eweida and others v. The United Kingdom, the Court observed that "In order to count as a "manifestation" within the meaning of Article 9, the act in question must be intimately linked to the religion or belief" (my emphasis). While this link must be firm and established, it does not hinge on the specific prescriptions of a religion or authoritative system of thought. Rather, the court stressed that "... the existence of a sufficiently close and direct nexus between the act and the underlying belief must be determined on the facts of each case."

\footnotetext{
${ }^{2}$ Cited first in Campbell and Cosans v. The United Kingdom (Application no. 7511/76; 7743/76) para. 36, 1982, and then repeatedly reiterated in subsequent decisions.

${ }^{3}$ UN Human Rights Committee (HRC), CCPR General Comment No. 22: Article 18 (Freedom of Thought, Conscience or Religion), 30 July 1993, CCPR/C/21/Rev.1/Add.4, available at: http://www.refworld.org/docid/453883fb22.html [accessed 15 October 2018]

${ }^{4}$ CCPR General Comment No. 22: Article 18 (Freedom of Thought, Conscience or Religion). Adopted at the Forty-eighth Session of the Human Rights Committee, on 30 July 1993 (CCPR/C/21/Rev.1/Add.4), para. 4.

${ }^{5}$ Eweida and others $v$. The United Kingdom (Application nos. 48420/10, 59842/10, 51671/10 and 36516/10), 2013, premise 82 .
} 
courts to extend the scope of the right both in terms of recognized beliefs, including "implicit" commitments and integrating foci, and protected acts, including those acts that may not be inspired by orthodox or canonical sets of beliefs, i.e. the "lived" aspects of religion.

\section{Explicating Religion in IHRL}

Although this approach appears to provide robust protections, both for "implicit" and "lived" forms of religion, it also destabilizes the vocabulary of law when faced with cases concerning the freedom of religion or belief. If protections under the right are principally available to any kind of belief and the "nexus" requirement between beliefs and acts must be asserted according to the facts of each case, every new claim related to religion potentially becomes an island unto itself, leaving the contents and scope of the required nexus underdetermined and opaque.

By opening up the scope of the freedom of religion or belief in this way, the HRC and the ECtHR have effectively embraced a conception of "religion" that invalidates clear-cut distinctions between protected beliefs and acts measured against any established or "traditional" forms of religion. In principle, this serves to erode and contest the strictures and constraints of formalized religious authority, essentially leaving the determination of protected beliefs and the boundaries of acceptable manifestations to the legal system. While this shift of balance between formal religious authorities to that of the legal system is one of the basic building blocks of modern liberal democratic governance and the rule of law, it is also premised on the presumption that the ostensibly "secular" and neutral legal system is best suited to determine the acceptable contents of religious beliefs and their manifestations.

The process by which claims to authority and sincerity are translated from one social domain and to the vocabulary and taxonomy of law is certainly not unique to religion, but a general feature of the gradual "juridification" of society, lamented and discussed extensively in the work of Jürgen Habermas. As I and Pamela Slotte have argued elsewhere, however, the translation process engendered by the juridification of religion presents a range of specific constraints and complications that sets the legal regulation of religion apart from other social domains that become subject to juridification (Årsheim and Slotte 2017). These constraints range from the pronounced and prominent role of religion in modern constitutionalism and the rapid increase in regulatory efforts targeting "religion" around the world, and to the increase in litigation and legal controversies surrounding the boundaries between "good" and "bad" forms of religious allegiance and the overlapping jurisdictional claims between "religious" and "secular" legal systems. Taken together, these intertwined processes, which all pinpoint the back-and-forth between religion as a source of legal authority and as an object of legal regulation, present legislators and courts with a distinctive set of challenges when faced with religion-based claims.

Before the ECtHR the distinctiveness of religion as a subject matter for law can first and foremost be detected in the erratic and unpredictable jurisprudence of the court on religion. From its earliest forays into case-law on religion in the 1950s and up to the present, the court has struggled to come to terms with the content and scope of article 9 of the ECHR. While there is a whole scholarly subfield dedicated to the analysis of where the court will go next in its interpretation of this article, scant attention has been paid to the methodology of the court in dealing with the connection between wide-ranging, "implicit" beliefs and the more eclectic, "lived" and wide-ranging manifestation of such beliefs.

An early indication of the European court's approach to this question is evident in the case of Arrowsmith v. United Kingdom (Application no. 7050/75, 1978). In this case, Pat Arrowsmith, a well-known, longtime anti-war protester, was convicted to 18 months imprisonment for violating the Incitement to Disaffection Act by distributing leaflets to army troops "endeavouring to seduce them from their duty of allegiance". Arguing that her conviction and sentence interfered with her right to manifest her pacifist 
beliefs, she presented her case to the European Commission of Human Rights, ${ }^{6}$ which accepted the claim that her pacifist beliefs, understood as "a philosophy of securing one's political or other objectives without resort to the threat or use of force against another human being under any circumstances" was eligible for protection under article 9(1). Hence, the court viewed her pacifist stance as "implicitly" religious in the sense intended by Edward Bailey.

In its consideration of whether the distribution of leaflets constituted a "practice" of this belief, however, the commission observed that:

It is true that public declarations proclaiming generally the idea of pacifism and urging the acceptance of a commitment to non-violence may be considered as a normal and recognized manifestation of pacifist belief. However, when the actions of individuals do not actually express the belief concerned they cannot be considered to be as such protected by Art. 9(1), even when they are motivated or influenced by it. [my emphasis]

Examining the contents of the leaflets, which contained quotes about the troubles in Northern Ireland from former soldiers, the commission found that the message was neither sufficiently pacifist, nor sufficiently general in nature to constitute a "practice" of pacifism. Rather, the message more specifically targeted British policy in Northern Ireland, and as such was not "actually" an expression of her principled pacifism, but a specific political claim which could have been formulated by a non-pacifist as well.

The decision in Arrowsmith illustrates how a big-tent definition of "belief", while setting an important precedent for later decisions on the admissibility of claims concerning non-orthodox convictions, can be of little use to claimants whose avenues for displaying allegiance to such beliefs are constricted by a narrow reading of what constitutes eligible "manifestations". In its subsequent jurisprudence, the "test" devised in Arrowsmith - whether the manifestation in question "actually" expresses the belief concerned, or if they are merely "motivated or influenced by it" - has been determinative, setting the tone for how the court dealt with the nexus requirement for decades (Taylor 2005). Importantly, the "test" is little more than a play on words, as the distinction between acts that constitute an "actual expression" and acts that merely evoke "motivation or influence" can hardly be set without retorting to what Hussein Ali Agrama has characterized as "often-unarticulated understandings about what religion in the abstract is, or should be" (Agrama 2010: 503).

While such often-unarticulated understandings are a necessary and unavoidable part of any legal determination of "religion", the determination of religion at the international level is faced by the particular predicament of working almost entirely in the abstract. Bereft of the historical and contextual constraints of domestic courts, the court has been forced to determine cases on religion as if it was the very trans-historical universal that Edward Bailey appeared to consider it to be. On this reading, "religion" necessarily becomes devoid of specific contents like doctrines, organizational structures, historical presence or pre- and proscribed practices, but becomes all the more overdetermined in its general form, which is constituted by having a set of intensive, internal commitments that can have the "extensive effects" formulated by Bailey.

One instructive example of how the court understands this general form is its much-discussed case-law on Islam: Strikingly, only two of the numerous cases concerning the display of Islamic symbols or dress argued before the court have been successful, a fact which has become the subject of much scholarly

\footnotetext{
${ }^{6}$ Until 1998, all cases presented to the ECtHR were filtered through the European Commission of Human Rights.
} 
scorn: While Peter Danchin asserts that Islam has become subject to review from the "majoritarian cultural norm" of Western, Christian-style secularism (Danchin 2011: 745), Nehal Bhuta has claimed that the court's decision in the Islam cases illustrate the perceived need for a "cultural defense" of the idea of a Christian Europe:

The institutionalized casuistry of a human rights court becomes the conduit for resuscitating an idea of European identity that had perhaps become dormant in light of the declining religiosity of the people of Europe since 1960.

Bhuta 2014: 32

Other commenters have been more modest in their criticism: Reviewing the court's decisions in the Dahlab v. Switzerland (Application No. 42393/98, 2001), Refah Partisi v. Turkey (Applications nos. 41340/98, 41342/98, 41343/98 and 41344/98 2003)s and Leyla Sahin v. Turkeyi (Application no. 44774/98, 2004) cases, all of which were decided against Muslim applicants, Javier Martínez-Torrón has noted a certain "prejudice" in the court's considerations of Islamic doctrines and their purported compatibility with democratic society (Martinez-Torrón 2018: 296-298).

A string of recent decisions on claims lodged by Muslim applicants may, however, indicate that this tide may be about to turn: In the curiously under-reported cases of Ahmet Arslan and others v. Turkey (Application no. 41135/98, 2010), Izzettin Dogan and Others v. Turkey (Application no. 62649/10, 2016) and Hamidovic v. Bosnia-Hercegovina (Application no. 57792/15, 2017), the court consistently found in favor of Muslim applicants, finding that their rights under article 9 had been illegitimately violated by state incursion. Ahmet Arslan and Izzettin Dogan both concerned the recognition of religious minorities in Turkey, a country which has traditionally been granted a particularly wide margin of appreciation, backed up by the court's assertion that the limitation of Islamic expressions in the public sphere constituted a real and present threat to the fragile Turkish democratic order. ${ }^{7}$ In Ahmet Arslan, the court found that the blanket ban on the specific attire of a small, Islamic sect in all public places could not be conceived as a legitimate limitation in the interests of public order or safety, as there was nothing to indicate that their mere presence in public places threatened these values. The case carefully limited its approach from the reasoning in Leyla Sahin by pointing out that the matter may be differently viewed if the ban was limited to "public establishments, where religious neutrality might take precedence over the right to manifest one's religion". Despite this delimitation, Ahmet Arslan is a landmark decision, as it is the very first time Islamic claimants have won in a case concerning the display of Islamic dress or symbols.

Izzettin Dogan, on the other hand, gave a rarely clear-cut confirmation of a scholarly hypothesis by bringing to fruition the "religionization" of Alevism predicted in 2008 by Markus Dressler, who observed that

[i]n a sense, Turkish laicism's obsessive anxiety about religion and its regulation pushes Alevism in a more thoroughly "religious" direction. The Sunni-dominated discourse as molded through Turkish laicism exerts a strong pressure on Alevis to streamline and theologize their beliefs. In order to be taken

\footnotetext{
${ }^{7}$ This is particularly the case in the Refah Partisi case, where the court flatly observed that "...It is difficult to declare one's respect for democracy and human rights while at the same time supporting a regime based on sharia, which clearly diverges from Convention values, particularly with regard to its criminal law and criminal procedure, its rules on the legal status of women and the way it intervenes in all spheres of private and public life in accordance with religious precepts. ... In the Court's view, a political party whose actions seem to be aimed at introducing sharia in a State party to the Convention can hardly be regarded as an association complying with the democratic ideal that underlies the whole of the Convention".
} 
seriously as a player in Turkey's religio-political field, many Alevis feel that they have to first systematically reconstruct and solidify their tradition.

Dressler 2008: 295

Izzettin Dogan originated in the long-standing refusal of the Turkish state to recognize Alevism as a distinctive religious tradition whose establishments and clergy should be eligible for the same kinds of privileges and rights as mainstream Sunni Islam. After performing the very "streamlining" and "theologization" of their beliefs highlighted by Dressler, however, the Alevi claimants in Izzettin Dogan won their case before the ECtHR, which observed that

the main argument relied on by the Government as justification for this difference in treatment is based on a theological debate concerning the place of the Alevi faith within the Muslim religion. The Court has already responded to this argument by finding that such an approach is inconsistent with the State's duty of neutrality and impartiality towards religions (see paragraphs 120 to 124 above) and clearly oversteps the State's margin of appreciation in choosing the forms of cooperation with the various faiths (see paragraph 132 above).

In coming to the conclusion that the state was barred from basing its differential treatment on a "theological debate", however, the court effortlessly took a stand in the very same theological debate, by asserting that "...the Alevis form a religious community which has distinctive characteristics in numerous spheres including theological doctrine, principal religious practices, places of worship and education.". This assertion was backed up by the court's reference to its earlier jurisprudence regarding the purported status of Alevism as a religion distinctive from Sunni Islam in the case of Hasan and Eylem Zengin v. Turkey (Application no. 1448/04, 2008), which concerned the teaching of religion in Turkish schools.

While Ahmet Arslan and Izzettin Dogan represent important adjustments in the court's view of the role of the state in recognizing or censoring different versions of the collective manifestation of Islamic belief, the case of Hamidovic v. Bosnia-Hercegovina was the first instance in which the court found in favor of an individual display of Islamic dress. The case originated in a terrorist attack against the US embassy in Sarajevo in 2011, performed by a local group advocating a Wahhabi/Salafi version of Islam. Mr. Hamidovic, who was a member of the group perpetrating the attack, was called to witness in the ensuing trial in 2012, but refused to remove his skullcap while in the courtroom. For this, he was expelled from the courtroom and sentenced to a fine. The Bosnian Constitutional Court stressed that the reaction was legitimate, because Bosnia-Hercegovina was a secular state in which religion was separated from public life, and that the reaction was intended to "support the values that bring people closer, and not those that separate them". After recognizing the dilemma of the state court in dealing with a religious manifestation originating in "a religious group opposing the concept of a secular state and recognizing only God's law", the ECtHR went on to stress that the applicant's right to manifest these beliefs should nevertheless be protected:

...the Court would emphasise that the authorities must not neglect the specific features of different religions. Freedom to manifest one's religion is a fundamental right: not only because a healthy democratic society needs to tolerate and sustain pluralism and diversity, but also because of the importance to an individual who has made religion a central tenet of his or her life to be able to communicate that belief to others (see Eweida and Others, cited above, § 94). The Court sees no reason to doubt that the applicant's act was inspired by his sincere religious belief that he must wear a skullcap at all times, without any hidden agenda to make a mockery of the trial, incite others to reject secular and democratic values or cause a disturbance (see, in this regard, Eweida and Others, cited above, § 81). 
Although the court stresses the need to keep "the specific features of different religions" in mind, the subsequent reasoning performs the exact opposite maneuver. Rather than reviewing the actual features of the appellant's religion, the court steered its attention in the direction of his demeanor - his sincerity and his lack of a hidden agenda or incitement against others to reject secular values or cause a disturbance. On this basis, the Bosnian court was found to have overstepped its margin of appreciation by penalizing his act. This is a far cry from the decisions of the court in Dahlab and Refah, both of which featured in-depth assessments of the "features" of Islam as a belief system, features that were deemed detrimental to democratic society. Hence, the generalized form of his religious manifestation - his sincere and modest demeanor - took precedent over its anti-democratic, anti-secularist contents, perfectly in line with Bailey's conception of "implicit" religion.

Shifting the perspective away from the contents of beliefs to the intensity and sincerity with which they become expressed represents a course correction that appears to be better in line with the scope of article 9 than the earlier jurisprudence of the court on Islam. However, a complete decoupling of the assessment of the scope of a "manifestation" of religion, belief or conscience from the contents of those beliefs leaves the court with no other option but to favor zealous, hardline, fundamentalist believers over those of a more gentle, complex and indirect disposition. Arguably, emphasizing form over contents in this way also risks tilting the balance for the strongly doctrinarian and hierarchical aspects of religion, and against less orthodox, more eclectic and "lived" manifestations of religion.

\section{Conclusion}

While this brief discussion only scratches the surface of the ECtHR case-law on religion, the larger conceptual point from this article that may merit further exploration concerns the interrelationship between "implicit" and "lived" forms of religion and the widespread "juridification" of society. If law and judicial reasoning is in fact expanding its interrelationship with religion, the research traditions and conceptual approaches offered by "implicit" and "lived" religion may be able to provide a more specific and finely tuned vocabulary to address the origins and consequences of this multidimensional process.

This is particularly the case for the freedom of religion or belief, whose prominence in the legal, political and academic sphere has risen exponentially over the course of the last decade. The legal formulation of this right is strikingly similar to the notion of implicit religion as it was developed by Edward Bailey: Both provide legislators and adjudicators with a concept of religion that recognizes traditional and nontraditional religious beliefs and their manifestations alike, as long as they retain the structural characteristics of internal, sincerely held convictions that give rise to external expressions. Similarly, the legal, political and scholarly elaboration of external, religious expressions that can or should merit protection under the right has grown exponentially over the course of the last decades. Relying on an expansive view of what constitutes "real", "everyday" or "lived" varieties of religious practice have pushed the original boundaries of the right in new and unusual directions.

Taken together, the profound width and depth of legal protections available for "religion" as the prominence of the freedom of religion or belief has grown has led to the point where both domestic courts and the ECtHR have little else to rely upon in their assessment of claims for protection than the question of whether "manifestations" of belief "actually" express that belief or not: Lacking any established methodology or yardstick with which to measure eligible beliefs or their manifestations, courts are left with sincerity and believability as the singular, unique item that can distinguish between eligible and ineligible claims.

While this may certainly act as a security against measuring the quality and contents of the specific beliefs and practices of different religious traditions, it conserves and arguably enhances the importance 
of the so-called "nexus" between beliefs and practices. Arguably, this trend will favor claimants such as Mr. Hamidovic, whose well-behaved demeanor and respectful attitude convinced the ECtHR that he harbored no ill will against the Bosnian court, despite his involvement with a group that was founded with the replacement of that very court with one based on their religious beliefs in mind.

\section{Literature}

Agrama, Hussein Ali. 2010. "Secularism, Sovereignty, Indeterminacy: Is Egypt a Secular or a Religious State?" Comparative Studies in Society and History 52 (3): 495-523.

Ammerman, Nancy T. 2016. "Lived Religion as an Emerging Field: An Assessment of Its Contours and Frontiers." Nordic Journal of Religion and Society 29 (2): 83-99.

Bailey, Edward. 1990. "The Implicit Religion of Contemporary Society: Some Studies and Reflections." Social Compass 37 (4): 483-97.

Bailey, Edward. 2009. "Implicit Religion." In The Oxford Handbook of the Sociology of Religion, edited by Peter B. Clarke, 801-15. Oxford: Oxford Handbooks Online, Oxford University Press..

Beaman, Lori. 2012. "Is Religious Freedom Impossible in Canada?" Law, Culture and the Humanities 8 (2): $266-84$.

Bhuta, N. 2014. "Two Concepts of Religious Freedom in the European Court of Human Rights." South Atlantic Quarterly 113 (1): 9-35

Danchin, Peter G. 2011. "Islam in the Secular Nomos of the European Court of Human Rights." Michigan Journal of International Law 32: 663-747.

Davis, Murray S. 1986. “'That's Classic!' The Phenomenology and Rhetoric of Successful Social Theories." Philosophy of the Social Sciences 16 (3): 285-301.

Dressler, Markus. 2008. "Religio-Secular Metamorphoses: The Re-Making of Turkish Alevism." Journal of the American Academy of Religion 76 (2): 280-311.

Gorski, Philip S. 2000. "Historicizing the Secularization Debate: Church, State, and Society in Late Medieval and Early Modern Europe ca. 1300 to 1700." American Sociological Review 65 (1): 138-67.

Gorski, Philip S., and Ateş Altınordu. 2008. “After Secularization?” Annual Review of Sociology 34 (1): $55-85$.

Hanson, Sharon. 2007. “The Sacred Paradox of English Law.” Implicit Religion 10 (1): 8-37.

Hurd, Elizabeth Shakman. 2015. Beyond Religious Freedom: The New Global Politics of Religion. Princeton: Princeton University Press.

Itzcovich, G. 2013. "One, None and One Hundred Thousand Margins of Appreciations: The Lautsi Case." Human Rights Law Review 13 (2): 287-308.

Martínez-Torrón, Javier. 2018. "Strasbourg' s Approach to Religion in the Pluralist Democracies of Europe." In Magna Carta, Religion and the Rule of Law, edited by R. Griffith-Jones and M. Hill, 281300. Cambridge: Cambridge University Press. 
McIvor, Méadhbh. 2015. "Carnal Exhibitions: Material Religion and the European Court of Human Rights.” Ecclesiastical Law Journal 17 (1): 3-14.

Pelkmans, Mathijs. 2014. "Paradoxes of Religious Freedom and Repression in (Post-) Soviet Contexts." Journal of Law and Religion 29 (3): 436-46.

Su, Anna. 2016. "Judging Religious Sincerity." Oxford Journal of Law and Religion 5 (1): 28-48.

Sullivan, Winnifred Fallers. 2005. The Impossibility of Religious Freedom. Oxford: Princeton University Press.

Taylor, Paul M. 2005. Freedom of Religion - UN and European Human Rights Law and Practice. Cambridge: Cambridge University Press.

Årsheim, Helge and Pamela Slotte. 2017. “The Juridification of Religion?”. In Brill Research Perspectives on Law and Religion 1 (2): 1-89. 